\title{
Sources of Polycyclic Aromatic Hydrocarbons in South China Sea Short Core Sediments Off Southern Part Terengganu, Malaysia and Multivariate Statistics Approaches \\ (Punca Hidrokarbon Aromatik Polisiklik di Teras Sedimen Pendek Laut China Selatan di Bahagian Selatan Terengganu, Malaysia dan Pendekatan Statistik Multivariat)
}

\author{
Swee Yun Pang, Suhaimi Suratman*, Yit Siang Hit, Bernd R.T. Simoneit \& Norhayati Mohd Tahir
}

\begin{abstract}
Sediment cores from the southern South China Sea off the Terengganu coast were analyzed for polycyclic aromatic hydrocarbons (PAHS) and perylene. The concentrations of total 17 PAH (TPAHs) and perylene varied between 5.45-27.7 $\mathrm{ng} / \mathrm{g}$ and 0.51-7.77 ng/g, respectively. Analyses of variance showed significant differences between the stations, but not in sub-bottom depths at the 0.05 level. The PAH cross plots showed a predominance of pyrogenic over petrogenic PAHs. Principal component analysis (PCA) showed clustered PAHs that are correlated with total organic carbon (TOC), indicating the importance of surface runoff via fluvial transport for contributing these PAHs to the coastal environment of the study area. Overall, the concentrations of PAHs in the study area are considered to be in the low range, not exceeding the $100 \mathrm{ng} / \mathrm{g}$ mark.
\end{abstract}

Keywords: Fluvial transport; PAHs; perylene; pyrogenic; southern South China Sea

\section{ABSTRAK}

Teras sedimen yang diambil di selatan Laut China Selatan, luar pesisir Terengganu telah dikaji untuk hidrokarbon aromatik polisiklik (PAH) dan perilena. Kepekatan jumlah 17 PAH (TPAH) dan perilena yang diperoleh masing-masing adalah 5.45-27.7 ng/g dan 0.51-7.77 ng/g. Keputusan analisis varians menunjukkan terdapat perbezaan yang signifikan antara stesen, tetapi tiada perbezaan pada kedalaman bawah dasar pada tahap 0.05. Plot silang PAH menunjukkan dominasi punca pirogenik berbanding PAH punca petrogenik. Analisis komponen utama (PCA) menampakkan PAH berkelompok berkorelasi dengan kandungan karbon organik(TOC), menunjukkan pentingnya larian permukaan melalui pengangkutan fluvium untuk menyumbang PAH kepada persekitaran pantai di kawasan kajian. Secara keseluruhan, kepekatan PAH di kawasan kajian adalah berada dalam julat rendah, tidak melebihi $100 \mathrm{ng} / \mathrm{g}$.

Kata kunci: PAH; pengangkutan fluvium; perilena; pirogenik; selatan Laut China Selatan

\section{INTRODUCTION}

Sediments serve as an ultimate sink and integrator of the pollutants that are adsorbed on suspended materials and deposited organic matter. The widespread organic pollutants, especially polycyclic aromatic hydrocarbons (PAHs), are included among these contaminants. The PAHs have been a subject of global interest due to their carcinogenic and mutagenic properties, capacity to bioaccumulate at higher trophic levels in the food chain, and their persistence in the environment (Fahmy \& Fahmy 1973). There are generally three common sources for PAHs: petrogenic (unburned petroleum and related products such as gasoline, kerosene, diesel, lubricating oil and asphalt, natural oil seeps, or any other spill events), pyrogenic (incomplete combustion of any organic matter, i.e. fossil fuels, biomass, waste incinerators $\&$ forest fire), and biogenic origin (natural inputs, e.g. higher plants, marine biomass and diagenetic products) 
(Page et al. 1999; Yunker et al. 1999). PAHs can be used as indicators for organic matter input from pyrogenic processes and utilization of fossil fuels. Diagnostic ratios between the PAH isomers, e.g. phenanthrene/anthracene, fluoranthene/pyrene, or chrysene/benz $[a]$ anthracene can be used as aids to constrain sources of PAHs in complex extract mixtures from sediments (Sicre et al. 1987; Wang et al. 1999).

Perylene is a five-ring PAH and has been reported as a diagenetic product derived from natural precursors (e.g. perylenequinone pigments) (Fan et al. 2011; Itoh et al. 2012; Jiang et al. 2000). Besides that, perylene can also be an indicator for decayed organic matter that can be transported from land to shelf. Evidence has indicated a possible relationship between perylene and termite nests in tropical top soils (Wilcke et al. 2002) and dead wood litter (Krauss et al. 2005), and in fossil wood remains affected by fungal activity (Bechtel et al. 2007; Marynowski et al. 2013). In addition to these sources, perylene can also be produced as a minor PAH from any combustion process of organic matter such as emissions from vehicles and biomass burning (Fine et al. 2002; Schauer et al. 2002; Silliman et al. 2000).

The southern South China Sea (SCS) off the Terengganu coast, Malaysia, is a biologically diverse area, characterized by its habitat and species diversity due to the presence of hundreds of smaller islands, submerged reefs, atolls, and banks. This region is also within active sea lanes, with maritime traffic linking the Kerteh crude oil terminal and Kemaman supply base to the offshore oil and gas exploration and production areas in the SCS off Peninsular Malaysia. Studies on PAHs derived from anthropogenic activities in sediments and on suspended particulate matter in river, lake, estuarine, and mangrove areas are well established for Malaysia (Assim et al. 2009; Bakhtiari et al. 2009; Elias et al. 2007; Mohd Tahir et al. 2011). However, an understanding of the extent of PAH accumulation, especially perylene, in coastal sediments of the SCS region, is still limited (Sakari et al. 2010a, 2010b; Wu et al. 2009; Zakaria et al. 2009). This study was initiated within the inner continental shelf of the SCS (within 5-50 km) off the Terengganu coast to assess the distribution and sources of perylene and PAHs, and how these inputs are reflected in recent sediments, to gain a better understanding of the processes controlling PAH deposition in marine sediments.

\section{MATERIALS AND METHODS}

\section{SAMPLING}

Three short core sediments $(12-32 \mathrm{~cm})$ (Figure 1) in southern South China were collected with a gravity corer during cruises in May 22-26, 2007 (post Northeast

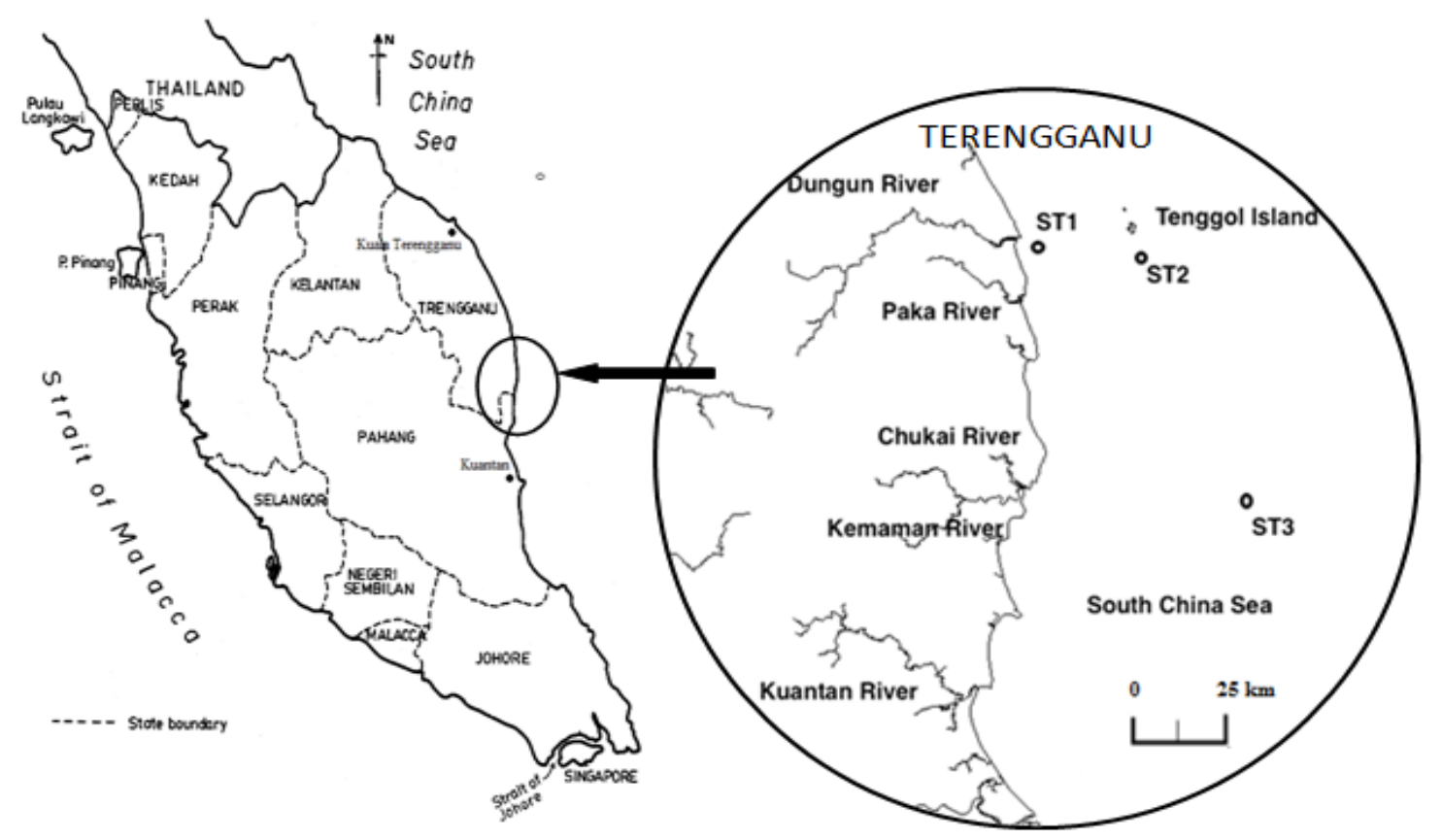

FIGURE 1. Location map of sampling sites 
monsoon) and September 4-9, 2007 (pre-Northeast monsoon), respectively. Station ST1, ST2 and ST3 are located approximate at 6,30 , and $45 \mathrm{~km}$, respectively, from coastline and the core lengths for ST1, ST2, and ST3 collected are around 22, 32, and $16 \mathrm{~cm}$, respectively. The profiles for ${ }^{210} \mathrm{~Pb}$ of cores from the SCS off the coast $\sim 100$ $\mathrm{km}$ north and $\sim 40 \mathrm{~km}$ south of this study area, showed sedimentation rates ranging between 1.2-1.4 mm/yr, with a surface mixed layer limited to the upper $10 \mathrm{~cm}$ (Wan Mahmood et al. 2010).

Once collected, core samples were kept refrigerated while being transported to the laboratory. In the laboratory, the cores were stored at $-4{ }^{\circ} \mathrm{C}$ until further analysis. Once thawed, each core was sectioned into $2 \mathrm{~cm}$ intervals and every section was then packed in an aluminum foil bag prior to freeze-drying. Freeze-dried sediments were then homogenized and sieved through $600 \mu \mathrm{m}$ mesh. Only the sieved samples $(<500 \mu \mathrm{m})$ were used for further analysis.

\section{EXTRACTION AND ANALYSIS}

Reagents and solvents of analytical and chromatographic grade were used. Total organic carbon (TOC) of the sediments was determined by the Walkley and Black titration method (Moris \& Singh 1971). Sieved sediments were Soxhlet extracted using hexane/dichloromethane $(1: 1 \mathrm{v} / \mathrm{v})$ as solvent. Before extraction, internal standards of phenanthrene- $d_{10}$ and perylene- $d_{12}$ were spiked into the sediment for recovery assessment. The sulfur in the sediment was removed using mercury treatment. The concentrated extracts were fractionated on $5 \%$ deactivated silica (230-400 mesh)-2\% deactivated alumina (70-230 mesh) columns. The aromatic fraction was eluted using $30 \mathrm{~mL} \mathrm{10 \%} \mathrm{dichloromethane} \mathrm{(DCM)}$ in hexane, followed by $25 \mathrm{~mL} \mathrm{50 \%} \mathrm{DCM} \mathrm{in} \mathrm{hexane.} \mathrm{The}$ 16 priority PAHs listed by the USEPA, i.e. naphthalene (Nap), acenaphthylene (Acp), acenaphthene (Ace), fluorene (Flu), phenanthrene (Phe), anthracene (Ant), fluoranthene (Fla), pyrene (Py), benz $[a]$ anthracene $(\mathrm{BaA})$, chrysene $(\mathrm{Chr})$, benzo[b]fluoranthene $(\mathrm{B} b \mathrm{~F})$, benzo $[k]$ fluoranthene $(\mathrm{BkF})$, benzo $[a]$ pyrene $(\mathrm{BaP})$, indeno(1,2,3-cd) pyrene (Ind), dibenz $[a, h]$ anthracene (DBA), and benzo[ghi]perylene (BghiP) were analyzed. The sum of these compounds and benzo[e]pyrene $(\mathrm{BeP})$, is expressed as 'TPAHs'. Perylene (Pery) was excluded because it can be produced naturally.

Identification and quantification of aromatic hydrocarbons was carried out using a Shimadzu-QP2010 gas chromatograph-mass spectrometer (GC-MS) fitted with a BPX-5 SGE fused silica capillary column (30 m length $\times 0.32 \mathrm{~mm}$ i.d., $0.25 \mu \mathrm{m}$ film thickness). The MS was operated at full-scan in the electron impact mode $(70 \mathrm{eV})$ with a mass range between 45 and $600 \mathrm{da}$ (at a scan speed of $1.25 \mathrm{~s}$ ). The flow of the carrier gas (Helium, 99.9\% purity) was set with an initial flow of 2.0 $\mathrm{mL} / \mathrm{min}$, with pressure at $32.2 \mathrm{kPa}$ and average velocity of $51.3 \mathrm{~cm} / \mathrm{s}$. The injection port temperature was set to $290{ }^{\circ} \mathrm{C}$, and the column temperature was programmed as follows: hold at $50{ }^{\circ} \mathrm{C}$ for $1 \mathrm{~min}$ followed by an increase in temperature to $290{ }^{\circ} \mathrm{C}$ at $5{ }^{\circ} \mathrm{C} / \mathrm{min}$, and then hold isothermal for $15 \mathrm{~min}$. Peak verification was based on key fragment ions and retention time of injected external standards, and/or compared to those in GC-MS library mass spectra. The results were blank-subtracted, and the concentrations were corrected for the recoveries of internal standards. The recoveries for phenanthrene- $d_{10}$ and perylene- $d_{12}$ ranged from $90.8 \pm 5.38 \%$ and $87.1 \pm 4.63 \%$, with RSD less than $15 \%$, respectively.

Statistical analyses were conducted using Microsoft Excel and IBM SPSS 15.0 software (Chicago, IL). To reduce the sediment inhomogeneity, the results for each station during the respective sampling periods were averaged and reported as a single concentration. The data was then subjected to a two-way ANOVA test to determine differences among locations and depths. This was followed by conducting a Scheffe's contrast among pairs of means, testing for significance of mean differences, which were considered significant only with $\mathrm{p}$ values $<0.05$. Principal component analysis (PCA) was performed. Values below the detection limit were replaced with half of the detection limit for statistical calculation and normalized with TOC content. Bartlett's sphericity and Kaiser-Mayer-Olkin test (KMO) were performed in order to verify the sampling data adequacy for each variable in the PCA model, with a minimum acceptable KMO value of 0.50 . Communality was also checked with an acceptable value of $>0.50$ for each variable. The data set was then normalized with Kaiser normalization, followed by application of Varimax rotation to give a PCA projection. The biplot of the principal component factors was illustrated using XLstat.

\section{RESULTS AND DisCUSSION}

TOTAL ORGANIC CARBON

TOC was determined to assess its influence on $\mathrm{PAH}$ distributions. The average concentration of TOC for the 
three cores ranged from $0.51 \%-2.09 \%$ (Figure $2(\mathrm{a})$ ). The two-way analysis of variance (ANOVA) at $p<0.05$ showed that the TOC concentration of station ST1 was significantly different from ST2 and ST3, whereas no significant difference was observed between ST2 and ST3. Additionally, no difference was found with respect to depth profiles.

\section{POLYCYCLIC AROMATIC HYDROCARBONS}

The average concentration of the total 17 PAHs (TPAHs) identified for both sampling periods ranged from 5.4527.7 ng/g(Figure 2(b), Table 1). The highest TPAH values were found in the sub-surface sediments of core ST1 $(2-4 \mathrm{~cm})$, followed by ST3 $(6-8 \mathrm{~cm})$ and ST2 $(0-2 \mathrm{~cm})$. ANOVA showed that the TPAH concentrations of ST1 were significantly different from those of ST2 and ST3 $(p<0.05)$, whereas no significant difference was observed between ST2 and ST3, nor with depth.

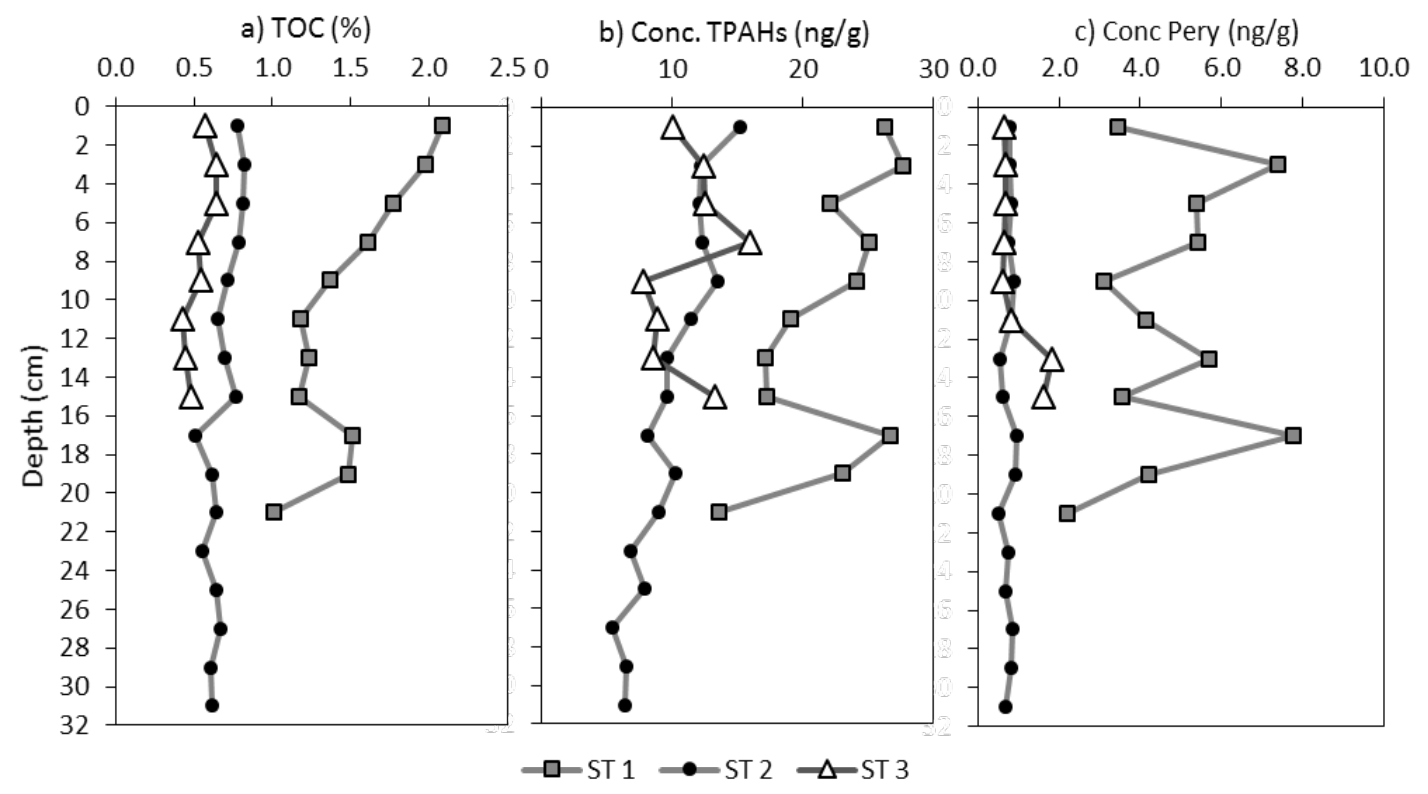

FIGURE 2. Vertical average concentration profile of (a) total organic carbon (TOC), (b) total PAHs (TPAHs) and (c) perylene in core sediments

TABLE 1. Mean concentrations of individual PAH (ng/g) and TOC (\%) in core samples

\begin{tabular}{lccccccccccccccc}
\hline $\begin{array}{l}\text { Station/ } \\
\text { Depth }\end{array}$ & TOC & Nap & Phe & Ant & Fla & Py & BaA & Chr & BbF & BkF & BeP & BaP & Pery & BghiP \\
\hline ST1 & & & & & & & & & & & & & & \\
$0-2$ & 2.09 & 14.74 & 3.75 & 0.21 & 2.32 & 3.08 & n.d. & n.d. & 1.01 & 0.27 & 0.74 & 0.22 & 3.46 & n.d. \\
$2-4$ & 1.98 & 13.43 & 5.70 & 0.41 & 2.92 & 4.00 & n.d. & n.d. & 0.54 & 0.17 & 0.32 & 0.20 & 7.40 & n.d. \\
$4-6$ & 1.77 & 11.48 & 3.26 & 0.25 & 1.87 & 2.55 & n.d. & n.d. & 1.52 & 0.12 & 0.74 & 0.14 & 5.39 & 0.21
\end{tabular}




$\begin{array}{lllllllllllllll}6-8 & 1.61 & 13.39 & 4.04 & 0.17 & 2.11 & 2.66 & 0.25 & 0.29 & 1.00 & 0.26 & 0.51 & 0.05 & 5.41 & 0.35 \\ 8-10 & 1.37 & 10.02 & 3.28 & 0.21 & 2.84 & 3.81 & 0.80 & 0.72 & 1.24 & 0.48 & 0.65 & 0.10 & 3.12 & \text { n.d. } \\ 10-12 & 1.18 & 10.19 & 2.35 & 0.16 & 1.53 & 2.04 & 0.09 & 0.13 & 1.02 & 0.34 & 0.55 & 0.25 & 4.13 & 0.47 \\ 12-14 & 1.24 & 8.30 & 2.43 & 0.11 & 1.79 & 2.19 & \text { n.d. } & \text { n.d. } & 1.04 & 0.27 & 0.34 & \text { n.d. } & 5.69 & 0.68 \\ 14-16 & 1.17 & 9.15 & 2.35 & 0.04 & 1.75 & 2.00 & \text { n.d. } & \text { n.d. } & 0.77 & 0.30 & 0.35 & 0.08 & 3.53 & 0.54 \\ 16-18 & 1.51 & 11.91 & 6.59 & 0.30 & 2.68 & 2.87 & \text { n.d. } & \text { n.d. } & 0.85 & 0.23 & 0.38 & \text { n.d. } & 7.77 & 0.93 \\ 18-20 & 1.48 & 10.48 & 5.86 & 0.21 & 2.05 & 2.47 & \text { n.d. } & \text { n.d. } & 0.74 & 0.27 & 0.30 & \text { n.d. } & 4.22 & 0.69 \\ 20-22 & 1.01 & 7.49 & 3.02 & \text { n.d. } & 0.78 & 0.95 & \text { n.d. } & \text { n.d. } & 0.67 & \text { n.d. } & 0.24 & \text { n.d. } & 2.19 & 0.43\end{array}$

ST2

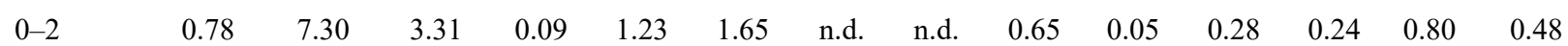

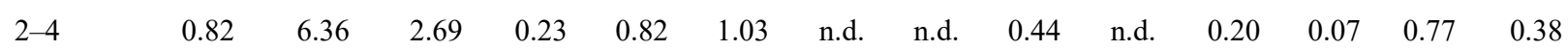

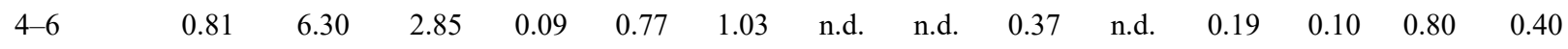

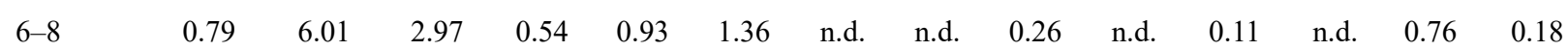

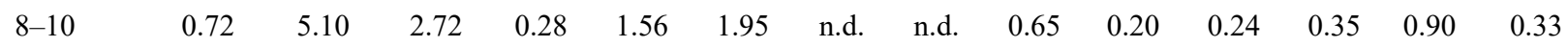

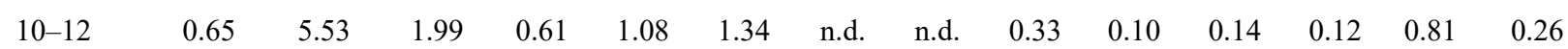

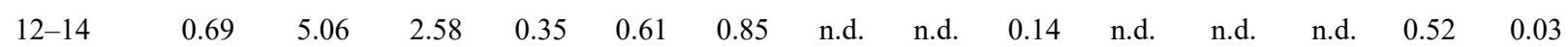

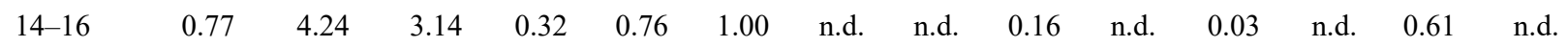

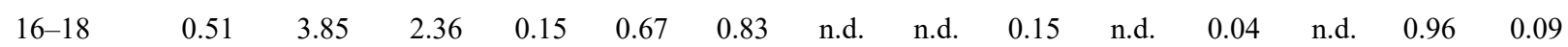

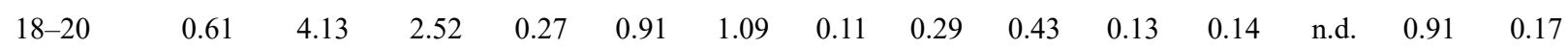

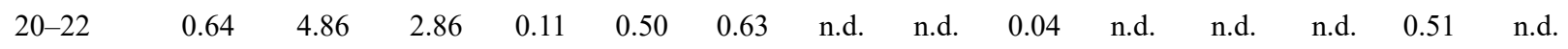

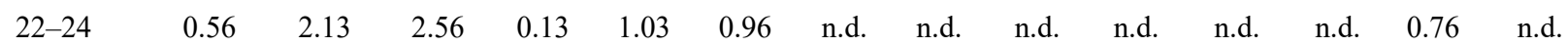

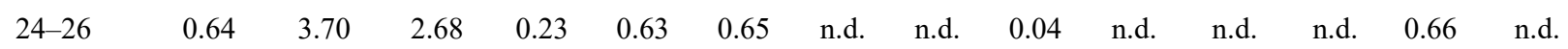

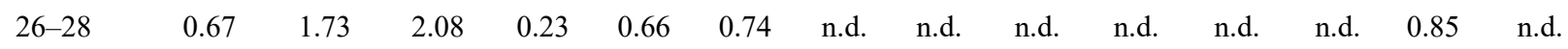

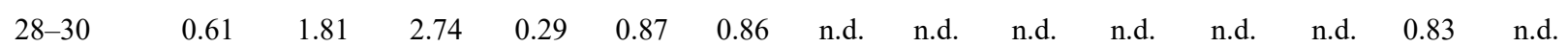

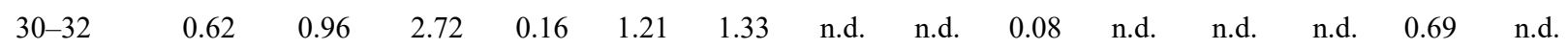

ST3

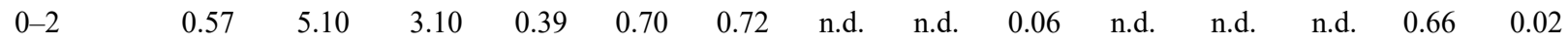

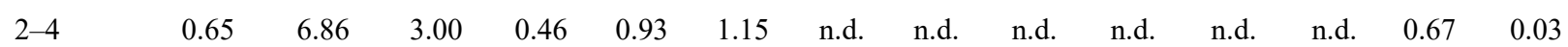

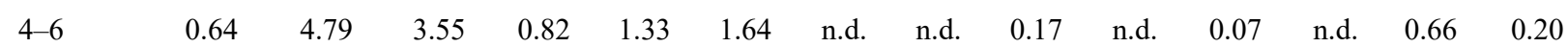

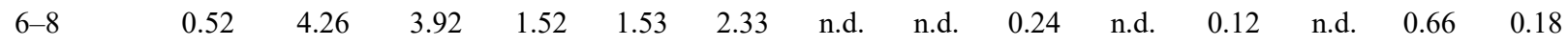

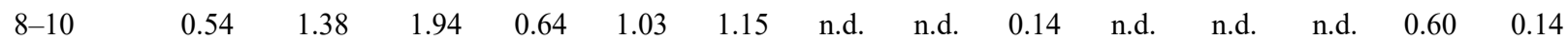

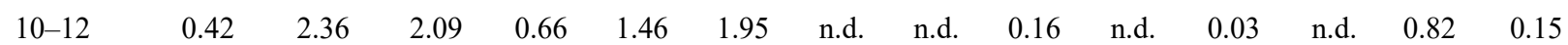

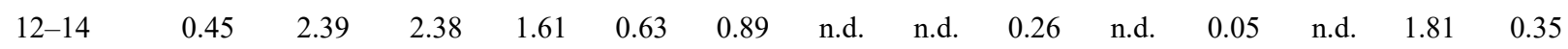

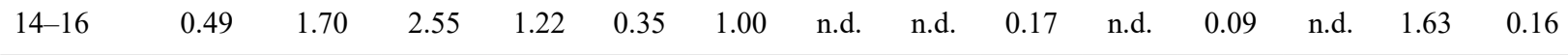


Table 2 compares the TPAH results of this study with those in previous literature, for sediments from Malaysian and worldwide coastal waters. These results are comparable to other reports which include the reports on coastal Rajang Sarawak (1.32-50.4 ng/g) (Assim et al. 2009), Dungun (208 ng/g) (Elias et al. 2007), offshore
Straits of Malacca (4.00-73.0 ng/g) (Zakaria et al. 2002), and Pengerang, Johor (2.5-142.8 ng/g) (Mohd Tahir et al. 2004); but are lower than previously reported in coastal sediments of Kota Bharu-Johor (188-438 ng/g) (Elias et al. 2007), near Malacca (25.0-2183 ng/g) (Sakari et al. 2010a), South China Sea (24.7-275 ng/g) (Yang 2000),

TABLE 2. Comparison of total concentrations of PAHs (TPAHs) in sediments from Malaysian and worldwide coastal waters

\begin{tabular}{|c|c|c|}
\hline Areas & Concentration & References \\
\hline $\begin{array}{l}\text { Southern Terengganu waters, Malaysia } \\
\text { (coastal, Dungun-Kemaman) }\end{array}$ & $\begin{array}{l}10.1-26.3 \mathrm{ng} / \mathrm{g}(0-2 \mathrm{~cm}) \\
5.45-27.7 \mathrm{ng} / \mathrm{g}(\text { core })\end{array}$ & Present study \\
\hline Kapas Island, Terengganu, SCS (coastal) & $\Sigma 16$ PAH: $2.00-76.0 \mathrm{ng} / \mathrm{g}$ (surface) & Chiu et al. (2015) \\
\hline $\begin{array}{l}\text { Pulau Cik Wan Dagang, Kemaman Malaysia } \\
\text { (mangrove) }\end{array}$ & $\begin{array}{l}\frac{\text { Surface sediments }}{\text { TPAHs }=120-1420 \mu \mathrm{g} / \mathrm{g} \text { (surface) }}\end{array}$ & Mohd Tahir et al. (2011) \\
\hline $\begin{array}{l}\text { Peninsular Malaysia } \\
\text { (coastal, offshore) }\end{array}$ & 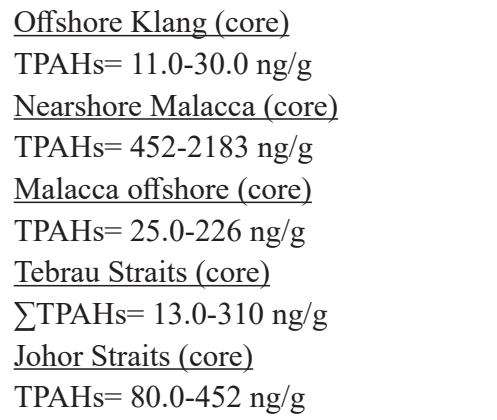 & Sakari et al. (2010a) \\
\hline Johor Straits, Malaysia (nearshore, straits) & $\begin{array}{l}\text { Johor City (core) } \\
\text { TPAHs }=44.6-1129 \mathrm{ng} / \mathrm{g} \\
\text { Johor Straits (core) } \\
\text { TPAHs }=68.6-521 \mathrm{ng} / \mathrm{g}\end{array}$ & Sakari et al. (2010b) \\
\hline $\begin{array}{l}\text { South China Sea, Malaysia (off coast sediment } \\
\text { from Kelantan to Johor) }\end{array}$ & $\sum \mathrm{TPAHs}=79.7-1481 \mathrm{ng} / \mathrm{g}$ (core) & Zakaria et al. (2009) \\
\hline Rajang Sarawak, Malaysia (coastal) & $\sum 16 \mathrm{PAHs}=1.32-50.4 \mathrm{ng} / \mathrm{g}$ (surface) & Assim et al. (2009) \\
\hline $\begin{array}{l}\text { Andaman Sea, Malaysia (off Langkawi, open } \\
\text { sea) }\end{array}$ & $\mathrm{TPAHs}=13.2-60.1 \mathrm{ng} / \mathrm{g}$ (core) & Wu et al. (2009) \\
\hline $\begin{array}{l}\text { Kota Bharu to Johor Baharu, East coast } \\
\text { Peninsular Malaysia (Coastal area) }\end{array}$ & $\begin{array}{l}\text { Kota Bharu to Johor Baharu (surface) } \\
16 \mathrm{PAHs}=188-438 \mathrm{ng} / \mathrm{g} \\
\text { Dungun (surface): } \\
16 \mathrm{PAHs}=208 \mathrm{ng} / \mathrm{g}\end{array}$ & Elias et al. (2007) \\
\hline Pengerang, Johor (coastal sediments) & TPAHs $=2.5-143 \mathrm{ng} / \mathrm{g}$ (surface) & Mohd Tahir et al. (2004) \\
\hline $\begin{array}{l}\text { Straits of Malacca, West coast Peninsular } \\
\text { Malaysia (offshore) }\end{array}$ & $\mathrm{TPAHs}=4.00-73.0 \mathrm{ng} / \mathrm{g}$ (surface) & Zakaria et al. (2002) \\
\hline South China Sea (open sea) & $\sum 11 \mathrm{PAHs}=24.7-275 \mathrm{ng} / \mathrm{g}($ surface $)$ & Yang (2000) \\
\hline $\begin{array}{l}\text { Northern South China Sea (off Pearl River } \\
\text { Estuary) (open sea) }\end{array}$ & $\sum 16 \mathrm{PAHs}=69-216 \mathrm{ng} / \mathrm{g}$ (core) & Peng et al. (2008) \\
\hline Weihai, East China & ¿16PAHs: $2.69-167 \mathrm{ng} / \mathrm{g}$ (surface) & Zhang et al. (2016) \\
\hline
\end{tabular}


Northern South China Sea (69-216 ng/g) (Peng et al. 2008) and Weihai, East China (2.69-167 ng/g) (Zhang et al. 2016). The TPAHs in this study are lower than the TPAHs reported in Johor Strait (68.6-1129 ng/g) (Sakari et al. 2010b) and in the SCS (covering Kelantan to Johor) (79.7-1481 ng/g) (Zakaria et al. 2009), but are higher than the Andaman Sea off Langkawi (13.2-60.1 ng/g) (Wu et al. 2009) and Kapas Island (2.00-76.0 ng/g) (Chiu et al. 2015). High PAH concentrations are usually reported in areas of close proximity to continental and industrial outflow; for example, the high concentrations of PAHs in the Malacca Strait were inferred to be from an increased usage of coal as the local industrial energy source (Sakari et al. 2010a). The distribution and levels of PAHs in the Johor Strait have been attributed to heavy shipping activities, and domestic and agricultural discharges (Sakari et al. 2010b), whereas the elevated PAHs in the SCS have been attributed to maritime activities, i.e. direct spillage of petroleum from gas and oil exploration and drilling activities in the area (Elias et al. 2007). Baumard et al. (1998) have classified the PAH concentrations in sediments into low, moderate, high, and very high for levels within the ranges of 0-100, 100-1000, 1000-5000, and $>5000 \mathrm{ng} / \mathrm{g}$, respectively. On this basis, the $\mathrm{PAH}$ concentrations in the southern SCS off Terengganu are in the low range, not exceeding $100 \mathrm{ng} / \mathrm{g}$. This could be due to dilution effects, since these stations are farther away from the coast ( $>5 \mathrm{~km}$ from land) and major offshore oil platforms.

\section{PAHs DIAGNOSTIC RATIOS}

Selected PAH diagnostic ratios were used for source assessment, i.e. the low molecular weight (LMW) PAHs (2- and 3-rings) to high molecular weight (HMW) PAHs (4- to 6-rings) [LMW/HMW], fluoranthene to (fluoranthene+pyrene) $[\mathrm{Fla} /(\mathrm{Fla}+\mathrm{Py})]$, and phenanthrene to anthracene) [Phe/Ant]. The values of the LMW/HMW ratios were mostly $>1$, showing a significant dominance of LMW PAHs. The HMW PAHs are likely from pyrogenic sources (i.e. combustion processes), whereas the LMW

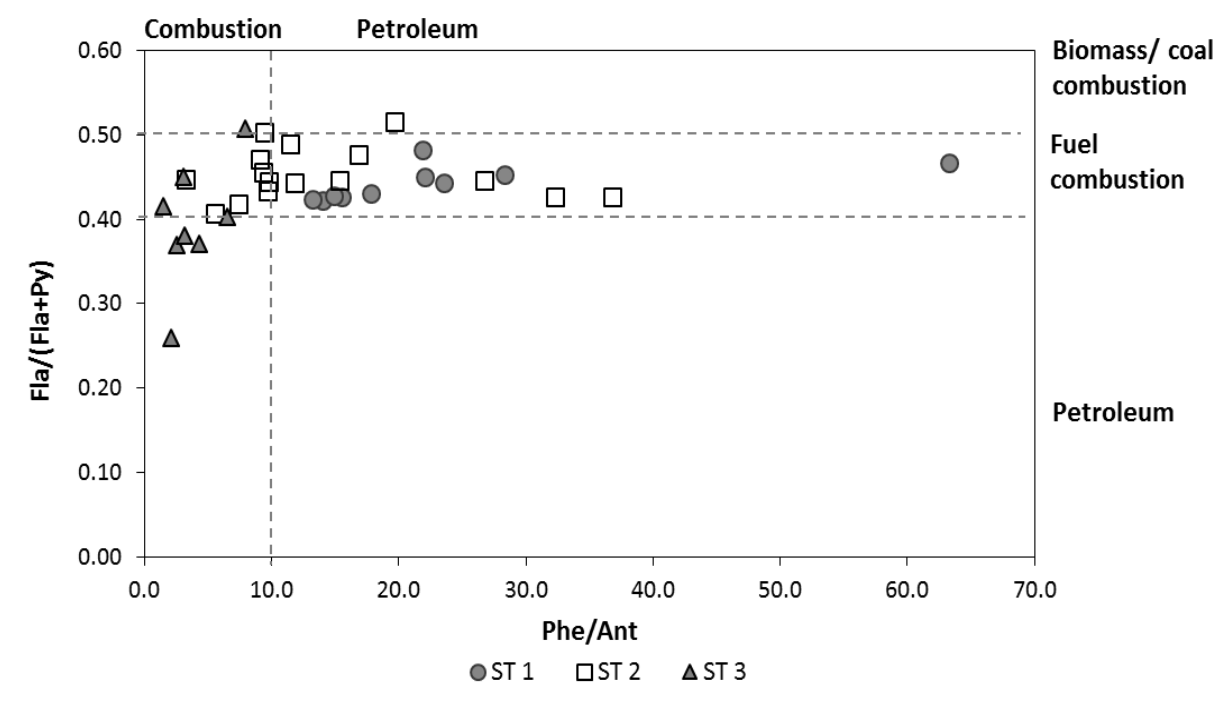

FIGURE 3. The cross plot of PAHs diagnostic ratio for Fla/(Fla+Py) and Phe/Ant ratios 
PAHs suggest a petrogenic origin (Yunker et al. 2015, 2002; Zakaria et al. 2002), or possibly from low temperature thermal alteration (Zaghden et al. 2007).

Furthermore, some of these compounds could in part be emissions from grass, hardwood, and softwood fires (Simoneit 2002). A cross plot shown below summarizes the diagnostic ratios for the selected PAHs in this study (Figure 3). The thermodynamically more stable PAH (i.e. phenanthrene) is usually more abundant than its less stable isomer (i.e. anthracene). The PAHs in ST1 and ST2 had Fla/(Fla+Py) in between 0.4-0.5 and Phe/Ant $>10$, indicating contamination from mixed petrogenic sources and combustion emissions, whereas ST3 was dominated by combustion sources (Phe/Ant $<10$ and Fla/(Fla + Py) $=$ $0.25-0.5)$.

\section{PERYLENE VERTICAL PROFILE}

The average concentration of perylene for the sampling periods ranged from $0.51-7.77 \mathrm{ng} / \mathrm{g}$ (Figure 2(c)), with the highest values in the sub-surface of ST1 $(2-4 \mathrm{~cm})$, followed by ST3 $(16-18 \mathrm{~cm})$ and ST2 $(12-14 \mathrm{~cm})$. ANOVA showed that the Pery concentration of ST1 was significantly different from ST2 and ST3 $(p<0.05)$, whereas no significant difference was obvious between ST2 and ST3. The depth profiles also showed no obvious trend $(p<0.05)$. The concentrations of perylene in the studied sites were found to be comparable to those reported in the SCS
(0.70-59.4 ng/g) (Yang 2000), in the Andaman Sea off Langkawi, Malaysia (21.2-41.3 ng/g) (Wu et al. 2009), and in coastal sediments in the SCS (11.0-43.0 ng/g) (Elias et al. 2007). The low Pery concentrations could be due to a weak input of terrigenous organic matter, the rapid degradation of perylenequinones (Bertrand et al. 2013), or an absence of binaphthyl as a potential precursor (Silliman et al. 2000).

In order to differentiate the inputs of biogenic, pyrogenic or diagenetically derived perylene, several researchers have calculated the percent concentration of perylene relative to the other pentacyclic aromatic isomers (PAI) [Pery/(BbF+BkF+BeP+BaP+Pery)] (Bakhtiari et al. 2009; Baumard et al. 1998). They have used a value of $>10 \%$ to indicate diagenetic processes on terrestrial organic matter, while values of $<10 \%$ indicate pyrolytic origins. On the other hand, Tolosa et al. (2004) used values of $<20 \%$ to indicate a pyrolytic origin. Interestingly, Bakhtiari et al. (2009) and Wang et al. (1999) also used the ratio of perylene to TPAHs to indicate its source, where a value of $1-4 \%$ was taken to indicate pyrogenic sources.

The vertical distributions of Pery/TPAH, Pery/PAI and pyrene/perylene for the samples are shown in Figure 4. The Pery concentration relative to TPAHs varied between $4.95 \%-24.9 \%$, Pery varied from $38.5 \%-100 \%$

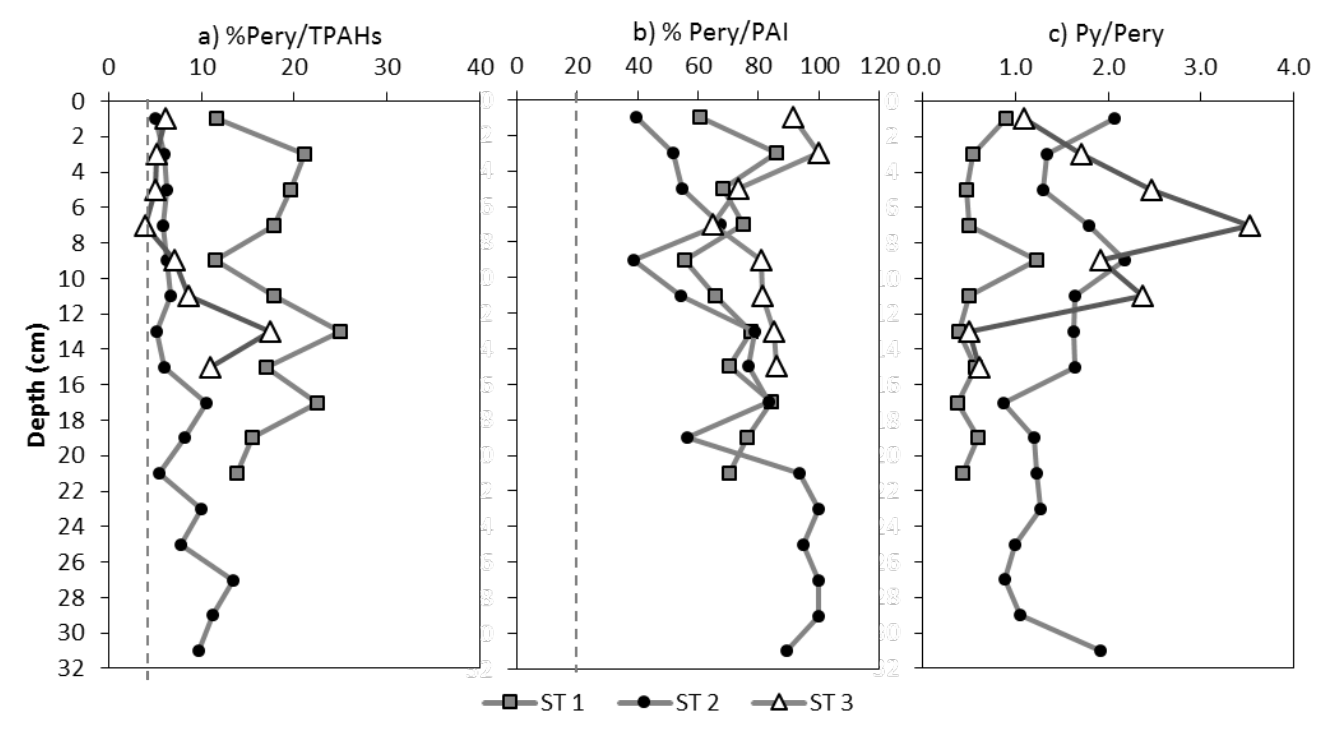

FIGURE 4. (a) Average perylene concentrations relative to total PAHs (b) Average perylene concentrations relative to pentacyclic-aromatic isomers (PAI), and (c) Average pyrene concentrations relative to perylene in core sediment 
of the PAI, and Py to Pery ranged from $0.37 \%-3.53 \%$. This shows that the perylene in all samples was derived from non-pyrogenic sources, most likely from natural origins (Marynowski et al. 2013; Tolosa et al. 2004). Bakhtiari et al. (2009) and Yunker et al. (1999) proposed that an increasing Pery concentration with depth indicated its diagenetic formation. However, here the Pery concentration decreased with increasing depth, which is in contrast to the trend reported by the other researchers. Although Pery decreased with depth, its concentration relative to TPAHs and PAI showed a gradual increase with depth. A similar observation was also reported by Silliman et al. (2000), who suggested that the decrease of Pery with depth, accompanied by an increase of Pery to TPAHs and PAI, was an indication of slow diagenesis.

\section{PRINCIPAL COMPONENT ANALYSIS}

Principal component analysis (PCA) was applied here to distinguish the distribution of the PAH sources among the cores. The PCA was based on the coefficient of correlation of variance for each variable. The first two eigenvectors (principal components, $\mathrm{PC} 1=34.83 \%$ and $\mathrm{PC} 2=24.82 \%$ ) accounted for $59.65 \%$ of the total variance. The loading variables are shown in Figure 5. The PC1 axis showed that most of the PAHs (Nap, PAI, Pery, BghiP) were clustered into a positive reading associated with TOC content, while the 3-4 rings PAHs (Fla, Py,. Phe, Ant) were clustered into a negative reading of $\mathrm{PC} 1$.

Most of the sections in core ST1 were found clustered into the positive scores of $\mathrm{PC} 1$, in which the surface sections of core ST1 were found to be predominant with Nap, while the lower sections of core ST1 were found predominant with high molecular weight PAHs (perylene, PAI and BghiP), indicating an abundant input of PAHs in core ST1. PAHs (Nap, Pery, PAI, and BghiP) that are clustered in a positive loading are found to be closely correlated with TOC, suggesting that these PAHs could be derived from mixed anthropogenic and biogenic sources transferred to the study sites via river runoff to the coastal waters. Naphthalene contributed over $40 \%$ to the TPAHs in core ST1. It is conceded that Nap is a pollutant that could originate from anthropogenic emission sources (e.g. incineration, coke ovens, incomplete combustion of gasoline, fuel, and biomass) (Khalili et al. 1995), and also from evaporation or sublimation of naphthalene-containing products (e.g. moth repellents, air fresheners) widely found in ambient and indoor air (Jia \& Batterman 2010). Nevertheless, naphthalene can also be present in biological production, e.g. detritus from plants, dead wood, litter, soils and termite nests found in

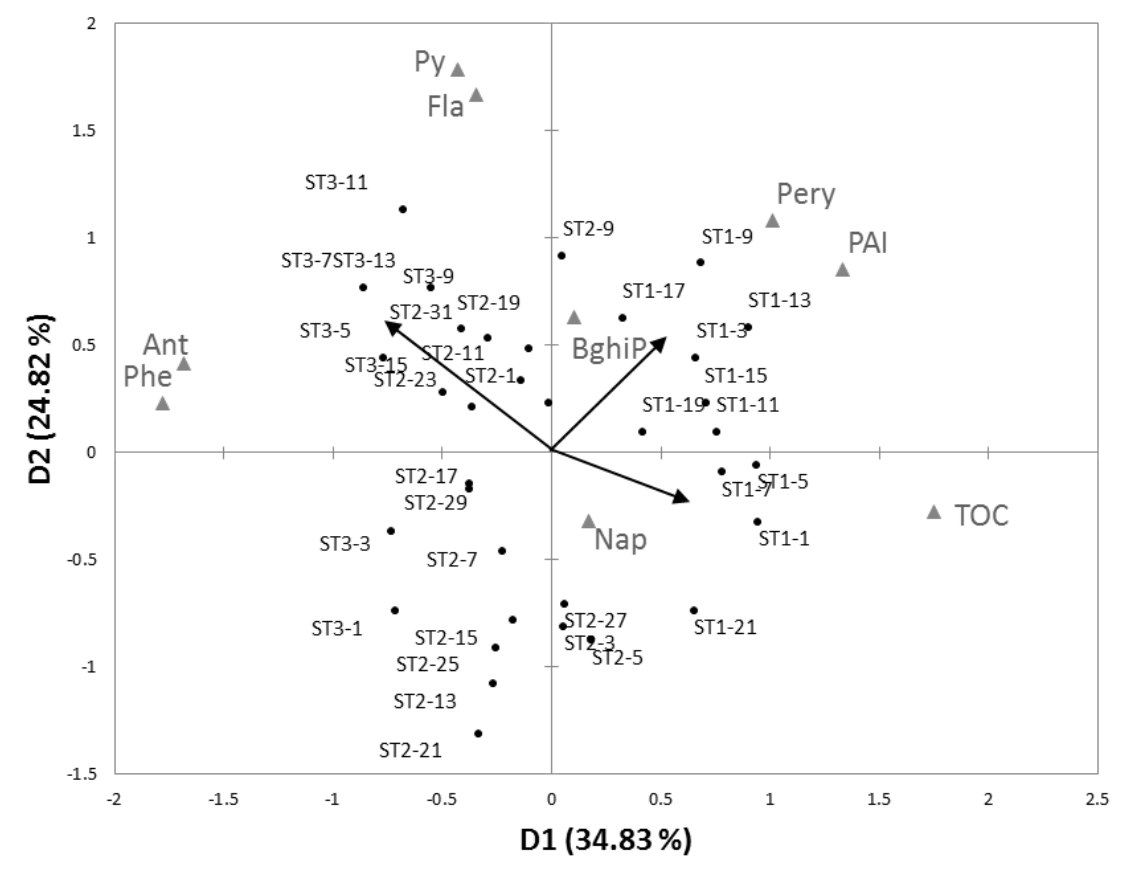

FIGURE 5. The loading plot of PCA for TOC-normalized PAHs in core sediments. Numbers indicate different sediment sections: 0-2 cm (1), 2-4 cm (3), 6-8 cm (5), 8-10 cm (7), 10-12 cm (9), 12-14 cm (11), 14-16 cm (13), $16-18 \mathrm{~cm}$ (15), 18-20 cm (17), 20-22 cm (21), 22-24 cm (23), 24-26 cm (25), 26-28 cm (27), 28-30 (29), and 30-32 cm (31) 
tropical regions (Krauss et al. 2005; Wilcke et al. 2002). The strong correlation between Nap and TOC in surface sections $(0-8 \mathrm{~cm})$ of core $\mathrm{ST} 1(\mathrm{r}=0.99, \mathrm{P}<0.05)$ supports the fact that its likely source was through fluvial transport from nearby land rather than emissions deposition. Pery in the surface section of ST1 on the other hand, showed a weak interaction with TOC, suggesting processes such as intensified monsoon dispersion, physical mixing (e.g. current circulation and dilution effect), and/or additional input of Pery (i.e. anthropogenic combustion) could contribute to this weak correlation.

The positive loading of PC2 axis grouped the PAHs with $>3$-rings, suggesting that these were derived from anthropogenic inputs (pyrogenic or petrogenic). PAH of Phe, Ant, Fla, and Py had grouped in negative scores of PC1 that were loaded with core ST2 and ST3, showing an abundance of inputs of PAHs in these cores. The PAH crossplot had showed that core ST3 was predominant in combustion derived sources. Thus, the PAHs in the negative loading of $\mathrm{PC} 1$ are indicative to be predominant in combustion derived inputs. In addition, most of the PAHs in core ST2 and ST3 that were clustered into negative loading of $\mathrm{PC} 1$ are found poorly correlated with TOC. These observations suggest that most of the PAH inputs in core ST2 and ST3 are not associated with river runoff, due to offshore dilution and long distance from river sources. Instead, the PAHs at these stations could be contributed from marine sources and possibly also from long range atmospheric deposition. The study area is within an active sea lane linking the Kemaman supply base to the oil and gas fields in the SCS, and the Terengganu crude oil terminal (TCOT) in Kerteh to the global demand centers (e.g. China and ASEAN countries). Therefore, these PAHs were deposited mainly from direct discharges of maritime activities.

\section{CONCLUSION}

The TPAH concentrations in sediments within the inner continental shelf of the southern South China Sea (5$50 \mathrm{~km})$ off Terengganu are considered low $(<100 \mathrm{ng} / \mathrm{g})$ on the pollution scale. However, this result may not be conclusive, because the distance from land point sources and processes such as monsoon seasons, physical mixing, biodegradation, and/or episodic input of PAH may influence the PAH distributions in the study area. The cross plot of diagnostic PAH ratios indicates that their distributions are characterized by a dominant input from pyrogenic sources, superimposed with petrogenic sources. The stations near land had the highest TPAHs and perylene. The PCA results had grouped stations with PAHs (e.g. Pery and Nap) that are closely correlated to TOC, indicating the importance of surface runoff from land by rivers in contributing to the overall burden of PAHs and perylene in this coastal environment. However, this importance decreases with distance from the coast.

\section{ACKNOWLEDGEMENTS}

The authors thank the Ministry of Science, Technology and Innovation (MOSTI), Malaysia for the financial support of this project (04-01-12-SF0065). This project was partly funded by the Ministry of Higher Education, Malaysia, through the Higher Institution Centre of Excellence (HICoE) Research Grant (Vote No. 66928) awarded to the Institute of Oceanography and Environment (INOS), Universiti Malaysia Terengganu. The technical staff of INOS, UMT is acknowledged for their support during sample collection. This paper is dedicated to the late Professor Law Ah Theem, who supported the initiation of this project.

\section{REFERENCES}

Assim, Z.A., Salleh, F. \& Nee, L.J.T.C. 2009. Aliphatic and polyaroamtic hydrocarbon in surface sediment from coastal areas of Rajang, Sarawak Malaysia. Proceedings of the International Conference on Marine Ecosystem: Transboundary Approach in Sustainable and Integrated Marine Resource Management. Pulau Langkawi (26-28 May 2009): INCOMES. p. 59.

Bakhtiari, A.R., Zakaria, M.P., Yaziz, M.I., Hj Lajis, M.N., Bi, X. \& Abd Rahim, M.C. 2009. Vertical distribution and source identification of polycyclic aromatic hydrocarbons in anoxic sediment cores of Chini Lake, Malaysia: Perylene as indicator of land plant-derived hydrocarbons. Applied Geochemistry 24: 1777-1787.

Baumard, P., Budzinski, H. \& Garrigues, P. 1998. Polycyclic aromatic hydrocarbons in sediments and mussels of the western Mediterranean Sea. Environmental Toxicology and Chemistry 17: 765-776.

Bechtel, A., Widera, M., Sachsenhofer, R.F., Gratzer, R., Lücke, A. \& Woszczyk, M. 2007. Biomarker and stable carbon isotope systematics of fossil wood from the second Lusatian lignite seam of the Lubsotw deposit (Poland). Organic Geochemistry 38: 1850-1864.

Bertrand, O., Montargès-Pelletier, E., Mansuy-Huault, L., Losson, B., Faure, P., Michels, R., Pernot, A. \& Arnaud, F. 2013. A possible terrigenous origin for perylene based on a sedimentary record of a pond (Lorraine, France). Organic Geochemistry 58: 69-77. 
Chiu, T.R., Mt Nanyan, N.F. \& Mohd Ali, M. 2015. Distribution of polycyclic aromatic hydrocarbons (PAHs) in surface sediments of Kapas Island, Terengganu, Malaysia, Procedia Environmental Science 30: 162-167.

Elias, M.S., Wood, A.K., Hashim, Z., Wee, B.S., Hamzah, M.S., Abd Rahman, S., Abd Salim, N.A. \& Talib, A. 2007. Polycyclic aromatic hydrocarbons (PAHs) contamination in the sediments of east coast Peninsular Malaysia. The Malaysian Journal of Analytical Sciences 11(1): 70-75.

Fahmy, O.G. \& Fahmy, M.J. 1973. Mutagenic properties of benzo(a)pyrene and its methylated derivatives in relation to the molecular mechanisms of hydrocarbon carcinogenesis. Cancer Research 33: 302-309.

Fan, C.W., Shiue, J., Wu, C.Y. \& Wu, C.Y. 2011. Perylene dominance in sediments from a subtropical high mountain lake. Organic Geochemistry 42: 116-119.

Fine, P.M., Cass, G.R. \& Simoneit, B.R.T. 2002. Chemical characterization of fine particle emissions from fireplace combustion of woods grown in the southern United States. Environmental Science and Technology 36: 1442-1451.

Itoh, N., Sakagami, N., Torimura, M. \& Watanabe, M. 2012. Perylene in Lake Biwa sediments originating from Cenococcum geophilum in its catchment area. Geochimica et Cosmochimica Acta 95: 241-251.

Jia, C. \& Batterman, S. 2010. A critical review of naphthalene sources and exposures relevant to indoor and outdoor air. International Journal of Environmental Research and Public Health 7: 2903-2939.

Jiang, C., Alexander, R., Kagi, R.I. \& Murray, A.P. 2000. Origin of perylene in ancient sediments and its geological significance. Organic Geochemistry 31: 1545-1559.

Khalili, N.R., Scheff, P.A. \& Holsen, T.M. 1995. PAH source fingerprints for coke ovens, diesel and gasoline engines, highway tunnels and wood combustion emissions. Atmospheric Environment 29: 533-542.

Krauss, M., Wilcke, W., Martinus, C., Bandeira, A.G., Garcia, M.V.B. \& Amelung, W. 2005. Atmospheric versus biological sources of polycylic aromatic hydrocarbons (PAHs) in a tropical rain forest environment. Environmental Pollution 135: 143-154.

Marynowski, L., Smolarek, J., Bechtel, A., Philippe, M., Kurkiewicz, S. \& Simoneit, B.R.T. 2013. Perylene as an indicator of conifer fossil wood degradation by wooddegrading fungi. Organic Geochemistry 59: 143-151.

Mohd Tahir, N., Fadzil, M.F., Ariffin, J., Maarop, H. $\& \mathrm{Hj}$. Wood, A.K. 2011. Source and distribution of hydrocarbons in mangrove sediments of Pulau Cik Wan Dagang, Kemaman. Journal of Sustainability Science and Management 6: 98-106.

Mohd Tahir, N., LI, H.L. \& Abdul Rashid, M.K. 2004. Hydrocarbons distribution in sediment of coastal areas of Penggerang. Johore. Paper on Proceedings of KUSTEM Research Seminar. Terengganu (May 31-June 2, 2004): KUSTEM. pp. 189-192.
Moris, N. \& Singh, M.M. 1971. Manual of Laboratory Method of Chemical Soil Analysis. Rubber Research Institute of Malaysia, Kuala Lumpur.

Page, D.S., Boehm, P.D., Douglas, G.S., Bence, A.E., Burns, W.A. \& Mankiewicz, P.J. 1999. Pyrogenic polycyclic aromatic hydrocarbons in sediments record past human activity: A case study in Prince William Sound, Alaska. Marine Pollution Bulletin 38: 247-260.

Peng, X., Wang, Z., Tang, C., Lu, H., Xu, S., Chen, F., Mai, B., Chen, S., Li, K. \& Yang, C. 2008. Temporal trends of hydrocarbons in sediment cores form Pearl River Estuary and northern South China Sea. Environmental Pollution 156: 442-448.

Sakari, M., Zakaria, M.P., Mohamed, C.A.R., Haji Lajis, N., Chandru, K., Bahry, P.S., Md. Sahfiee, M. \& Anita, S. 2010a. The history of petroleum pollution in Malaysia: Urgent for integrated prevention approach. Environmental Asia 3: 131-142.

Sakari, M., Zakaria, M.P., Mohamed, C.A.R., Haji Lajis, N., Chandru, K., Bahry, P.S., Mazlin, B.M. \& Shahbazi, A. 2010b. Urban vs. marine based oil pollution in the Strait of Johor, Malaysia: A century record. Soil and Sediment Contamination 19: 644-666.

Schauer, J.J., Kleeman, M.J., Cass, G.R. \& Simoneit, B.R.T. 2002. Measurement of emissions from air pollution sources. 5. $\mathrm{C}_{1}$ through $\mathrm{C}_{32}$ organic compounds from gasolinepowered motor vehicles. Environmental Science and Technology 36: 1169-1180.

Sicre, M.A., Marty, J.C., Saliot, A., Aparico, X., Grimalt, J. \& Albaiges, J. 1987. Aliphatic and aromatic hydrocarbons in different sized aerosols over the Mediterranean Sea: Occurrence and origin. Atmospheric Environment 21: 2247 2259.

Silliman, J.E., Meyers, P.A., Ostrom, P.H., Ostrom, N.E. \& Eadie, B.J. 2000. Insights into the origin of perylene from the isotopic analysis of sediments from Saanich Inlet, British Columbia. Organic Geochemistry 31: 1133-1142.

Simoneit, B.R.T. 2002. Biomass burning - A review of organic tracers for smoke from incomplete combustion. Applied Geochemistry 17: 129-162.

Tolosa, I., de Mora, S., Sheikholeslami, M.R., Villeneuve, J.P., Bartocci, J. \& Cattini, C. 2004. Aliphatic and aromatic hydrocarbons in coastal Caspian Sea sediments. Marine Pollution Bulletin 48: 44-60.

Wan Mahmood, Z.U., Mohamed, C.A.R., Yii, M.W., Ahmad, Z., Ishak, K. \& Ishak, A.K. 2010. Vertical inventories and fluxes of ${ }^{210} \mathrm{~Pb},{ }^{228} \mathrm{Ra}$ and ${ }^{226} \mathrm{Ra}$ at southern South China Sea and Malacca Strait. Journal of Radioanalytical Nuclear Chemistry 286: 107-113.

Wang, Z., Fingas, M., Shu, Y.Y., Sigouin, L., Landriault, M., Lambert, P., Turpin, R., Campagna, P. \& Mullin, J. 1999. Quantitative characterization of PAHs in burn residue and soot samples and differentiation of pyrogenic PAHs from petrogenic PAHsthe 1994 mobile burn study. Environmental Science and Technology 33: 3100-3109. 
Wilcke, W., Krauss, M. \& Amelung, W. 2002. Carbon isotope signature of polycyclic aromatic hydrocarbons (PAHs): Evidence for different source in tropical and temperate Environments? Environmental Science and Technology 36: 3530-3535.

Wu, Y.L., Wang, X.H., Li, Y.Y., Hong, H.S., Lin, H.Y. \& Yin, M.D. 2009. Over one hundred year sedimentary record of polycyclic aromatic hydrocarbons in the Andaman Sea, Malaysia. Environmental Science 30: 2512-2519.

Yang, G. 2000. Polycyclic aromatic hydrocarbons in sediments of the South China Sea. Environmental Pollution 108: 163171.

Yunker, M.B., Macdonald, R.W., Goyette, D., Paton, D.W., Fowler, B.R., Sullivan, D. \& Boyd, J. 1999. Natural and anthropogenic inputs of hydrocarbons to the Strait of Georgia. The Science of the Total Environment 225: 181209.

Yunker, M.B., Macdonald, R.W., Ross, P.S., Johannessen, S.C. \& Dangerfield, N. 2015. Alkane and PAH provenance and potential bioavailability in coastal marine sediments subject to a gradient of anthropogenic sources in British Columbia, Canada. Organic Geochemistry 89(90): 80116.

Yunker, M.B., Mcdonald, R.W., Vingarzan, R., Mitchell, R.H., Goyette, D. \& Sylvestre, S. 2002. PAHs in Fraser River basin: A critical appraisal of PAH ratios as indicators of PAHs source and composition. Organic Geochemistry 33: 489-515.

Zaghden, H., Kallel, M., Elleuch, B., Oudot, J. \& Saliot, A. 2007. Sources and distribution of aliphatic and polyaromatic hydrocarbons in sediments of Sfax, Tunisia, Mediterranean Sea. Marine Chemistry 105: 70-89.

Zakaria, M.P., Manan, N., Lee, C.Y. \& Mohamed, C.A.R. 2009. Distribution and sources of Polycyclic Aromatic Hydrocarbons (PAHs) in core sediment samples collected in South China Sea. Book Abstract of Pameran Rekacipta Penyelidikan dan Inovasi (PRPI) (28-30 Julai 2009): Perhutanan dan Alam Sekitar. p. 75.
Zakaria, M.P., Takada, H., Tsutsumi, S., Ohno, K., Yamada, J., Kouno, E. \& Kumata, H. 2002. Distribution of polycyclic aromatic hydrocarbons (PAHs) in rivers and estuaries in Malaysia: A widespread input of petrogenic PAHs. Environmental Science Technology 36: 1907-1918.

Zhang, D., Liu, J., Yin, P., Lin, X., Liu, N. \& Meng, X. 2016. Polycyclic aromatic hydrocarbons in surface sediments from the Coast of Weihai, China: Spatial distribution, sources and ecotoxicological risks. Marine Pollution Bulletin 109(1): 643-649.

Swee Yun Pang, Suhaimi Suratman* \& Norhayati Mohd Tahir Institute of Oceanography and Environment Universiti Malaysia Terengganu 21030 Kuala Nerus, Terengganu Darul Iman Malaysia

Yii Siang Hii

Pakar Scieno TW Sdn. Bhd.

25, Jalan Pengacara U1/48

Kawasan Perindustrian Temasya

40150 Shah Alam, Selangor Darul Ehsan

Malaysia

Bernd R.T. Simoneit

Department of Chemistry, College of Science

Oregon State University

Corvallis, Oregon 97331

USA

Norhayati Mohd Tahir

Faculty of Science and Marine Environment

Universiti Malaysia Terengganu

21030 Kuala Nerus, Terengganu Darul Iman

Malaysia

*Corresponding author; email: miman@umt.edu.my

Received: 9 November 2020

Accepted: 22 January 2021 